\title{
Management of Powdery Mildew on Ninebark Using Sanitizers, Biorational Products, and Fungicides
}

\author{
Fulya Baysal-Gurel and Ravi Bika
}

Department of Agriculture and Environmental Sciences, College of Agriculture, Tennessee State University, Otis L. Floyd Nursery Research Center, 472 Cadillac Lane, McMinnville, TN 37110

Additional index words. botanical-based compounds, chemical-based compounds, disease management, nursery production, Physocarpus opulifolius, Podosphaera physocarpi

\begin{abstract}
Ninebark (Physocarpus opulifolius) is a popular ornamental shrub and considered a hardy and tough plant that can thrive in different environmental conditions and resist diseases. However, powdery mildew, caused by Podosphaera physocarpi, can severely affect ninebark, deteriorating the ornamental value and making them unmarketable. Only a few studies have been done in managing powdery mildew of ninebark. The current study focuses on evaluating and identifying effective products (sanitizers, biorational products, and fungicides) for the management of powdery mildew disease of ninebark. A total of 12 treatments, including nontreated control, were studied. The experiment was arranged in randomized complete block design with four-single 'Mindia Coppertina ${ }^{\circledR}$, ninebark plant per treatment and repeated twice. Powdery mildew disease severity, growth parameters, and phytotoxicity were assessed in the study. All treatments significantly reduced the powdery mildew disease severity and disease progress [area under disease progress curve (AUDPC)] compared with the nontreated control. The treatments, such as azoxystrobin + benzovindiflupyr at 0.17 and $0.23 \mathrm{~g} \cdot \mathrm{L}^{-1}$ total active ingredients (a.i.) applied, chlorothalonil + propiconazole at $1.12 \mathrm{~mL} \cdot \mathrm{L}^{-1}$ total a.i. applied, azoxystrobin + tebuconazole at 0.11 and $0.16 \mathrm{~g} \cdot \mathrm{L}^{-1}$ total a.i. applied, and giant knotweed extract [Reynoutria sachalinensis $(0.5$ $\mathrm{mL} \cdot \mathrm{L}^{-1}$ total a.i. applied)] were the most effective treatments in reducing disease severity and disease progress in both trials. The treatments had no significant effects on the plant growth parameters such as height and width. In Expt. 2, azoxystrobin + benzovindiflupyr and hydrogen peroxide + peroxyacetic acid treated plants showed the low level of phytotoxic symptoms. The phytotoxicity of these two treatments in Expt. 2 could be related to higher environmental temperature during the experimental period.
\end{abstract}

Ninebark (Physocarpus opulifolius), which is also known as eastern ninebark or common ninebark, is a tough, durable deciduous shrub belonging to family Rosaceae and subfamily Spiraeoideae (Dirr, 1998; Zlesak, 2012). Ninebark is one of the 10 species of hardy deciduous shrubs native mainly to North America (Wheeler and Hoebeke, 1985), and it ranges from Quebec to Virginia, Tennessee, Michigan, and Minnesota (Dirr, 1998). It is

Received for publication 10 Jan. 2021. Accepted for publication $11 \mathrm{Feb} .2021$

Published online 26 April 2021.

We thank Terri Simmons and Christina Jennings for their help with experimental set up and review of the manuscript

This project was funded by the National Institute of Food and Agriculture (NIFA), United States Department of Agriculture (USDA) Evans-Allen grant, under award numbers TENX-1926-CCOCP and TENX-S-1083. Mention of trade names of commercial products in the publication is solely for the purpose of providing specific information and does not imply recommendation or endorsement by Tennessee State University.

F.B.-G. is the corresponding author. Email: fbaysalg@tnstate.edu.

This is an open access article distributed under the CC BY-NC-ND license (https://creativecommons. org/licenses/by-nc-nd/4.0/). characterized by exfoliating bark, which peels off in multiple papery sheets; alternately arranged, simple, roundish ovate and petiolate leaves having three to five crenate-dentate obtuse or acutish lobes and developing yellowish to bronze fall colors; plus whitish or pinkish flowers (Dirr, 1998, 2011). The popularity of ninebark as landscape ornamental has increased in the United States because of the variation of plant size, diverse foliage color (purple-yellow-green), and status as an indigenous plant (Lubell et al., 2011). Additional reasons for popularity as a landscape plant are its being able to adapt to difficult situations, being easy to grow, and being tolerant to variable soil moisture and soil $\mathrm{pH}$ (alkaline or acidic) (Lubell et al., 2011; Zlesak, 2012).

Ninebark is considered a hardy and persistent ornamental shrub; however, it can be severely affected by powdery mildew caused by Podosphaera physocarpi (Baysal-Gurel et al., 2020; Zlesak, 2012). The fungus is highly specialized and forms a close association with ninebark, and a condition of high relative humidity but dry leaves favors the incidence of powdery mildew (Pscheidt and Ocamb, 2000). The symptomatic plants exhibit witches'-broom with cream- to whitecolored, thickened shoots, curly leaves, and patches of a white, powdery fungal colony growing on the surface of leaves, stems, flowers, and fruits (Baysal-Gurel et al., 2020; Lubell et al., 2011; Pscheidt and Ocamb, 2000), reducing the ornamental characteristics of plants in landscapes. The cultivars showing resistance to powdery mildew were 'Nanus', 'Seward Summer Wine ${ }^{\circledR}$, and 'Luteus' for green, purple, and yellow foliage, respectively; whereas the yellow foliage cultivars such as 'Dart's Gold', 'Morning Star', and 'Nugget' were highly susceptible to powdery mildew (Lubell et al., 2011).

The presence of powdery mildew in container-grown 'Mindia Coppertina ${ }^{\circledR}$, ninebark was confirmed in a commercial nursery in Dekalb county, TN in 2016 (Baysal-Gurel et al., 2020). The disease severity was $40 \%$, and the disease incidence was found to be $60 \%$ after observing 1000 plants. It is critical to manage powdery mildew of ninebark to assist nursery growers to remain competitive in business. However, little study has been done in the field of managing powdery mildew in ninebark. The objective of this current study was to identify effective sanitizers, biorational products, and fungicides for the successful management of powdery mildew of ninebark. Those products were also evaluated for phytotoxicity on ninebark. The findings of this study can assist woody ornamental producers for better control of powdery mildew on ninebark.

\section{Materials and Methods}

Two experiments were conducted in 2016. Both experiments were conducted in two shade houses ( $56 \%$ shade) at a commercial nursery in DeKalb County, TN using 'Mindia Coppertina ${ }^{\circledR}$, plants grown in 3 -gal pots. Growing media consisted of $100 \%$ pine bark amended with $11.12 \mathrm{lb} / \mathrm{yard}^{3}$ $19 \mathrm{~N}-2.1 \mathrm{P}-7.4 \mathrm{~K}$ controlled-release fertilizer (Osmocote Pro; ICL Specialty Fertilizers, Dublin, $\mathrm{OH}), 1.01 \mathrm{lb} /$ yard $^{3}$ micronutrient fertilizer (Micromax; ICL Specialty Fertilizers), $1.01 \mathrm{lb} /$ yard $^{3}$ chelated iron (Fe) (10\%) (Sprint330; BASF, Florham, NJ), and $0.34 \mathrm{lb} /$ yard $^{3}$ Epsom salts containing $9.8 \%$ of magnesium $(\mathrm{Mg})$ and $12.9 \%$ of sulfur (S) (MagnaGrow; PQ Corporation, Valley Forge, PA). Each plant received $30 \mathrm{~g}$ of $18 \mathrm{~N}-6 \mathrm{P}-8 \mathrm{~K}$ 180-d controlled-release fertilizers (Florikan; Florikan ESA LLC, Sarasota, FL). Plants were irrigated via overhead sprinklers daily. No maintenance pesticides were applied in either experiment other than test products. Six products were evaluated as protective foliar applications for their ability to manage naturally occurring infection by powdery mildew caused by $P$. physocarpi of ninebark (Table 1). The treatments were applied according to recommended rates by registrants (Table 1). Each treatment had four single-plant replications that were arranged in a randomized complete block design. Plants were sprayed with treatments until runoff from the foliage, using a backpack carbon dioxide $\left(\mathrm{CO}_{2}\right)$-pressurized sprayer with a tapered edge flat spray pattern stainless steel nozzle (TP8002VS; TeeJet Technologies, Springfield, IL) at 40 psi. The control group did not receive any 
Table 1. List of treatments, active ingredients, trade names, and Fungicide Resistance Action Committee (FRAC) codes for the management of powdery mildew caused by Podosphaera physocarpi on 'Mindia Coppertina ${ }^{\circledR}$, ninebark plant. The control plant was nontreated ninebark naturally infected with powdery mildew.

\begin{tabular}{|c|c|c|c|}
\hline Treatment $^{z}$ & Active ingredient $(\%)$ & Trade name & Fungicide Resistance Action Committee (FRAC) code \\
\hline Azoxystrobin + benzovindiflupyr & $30 \%+15 \%$ & Mural & $11+7$ \\
\hline Azoxystrobin + tebuconazole & $11 \%+18.35 \%$ & Experimental product ${ }^{\mathrm{y}}$ & $11+3$ \\
\hline Chlorothalonil + propiconazole & $37.9 \%+2.97 \%$ & Concert II & M $05+3$ \\
\hline Hydrogen peroxide + peroxyacetic acid & $21.1 \%+2 \%$ & ZeroTol 2.0 & $\mathrm{NC}^{\mathrm{x}}$ \\
\hline Sodium carbonate peroxyhydrate & $85 \%$ & GCPRO & $\mathrm{NC}^{\mathrm{x}}$ \\
\hline Reynoutria sachalinensis extract & $5 \%$ & Regalia & P 05 \\
\hline
\end{tabular}

${ }^{\mathrm{z}}$ Treatment details: Azoxystrobin + benzovindiflupyr (Syngenta Crop Protection LLC, Greensboro, NC) at $0.37 \mathrm{~g} \cdot \mathrm{L}^{-1}(0.05 \mathrm{oz} / \mathrm{gal})$ and $0.52 \mathrm{~g} \cdot \mathrm{L}^{-1}(0.07$ oz/gal) application rate in 7 and $14 \mathrm{~d}$, respectively; azoxystrobin + tebuconazole $(\mathrm{OHP}, \mathrm{Bluffton}, \mathrm{SC}) \mathrm{at} 0.37 \mathrm{~g} \cdot \mathrm{L}^{-1}(0.05 \mathrm{oz} / \mathrm{gal})$ and $0.56 \mathrm{~g} \cdot \mathrm{L}^{-1}(0.075$ $\mathrm{oz} / \mathrm{gal})$ application rate in $14 \mathrm{~d}$ interval; chlorothalonil + propiconazole (Syngenta Crop Protection LLC) at $2.34 \mathrm{~mL} \cdot \mathrm{L}^{-1}(0.30 \mathrm{fl} \mathrm{oz} / \mathrm{gal}) \mathrm{and} 2.73 \mathrm{~mL} \cdot \mathrm{L}^{-1}$ $(0.35 \mathrm{fl} \mathrm{oz} /$ gal) application rate in 7 and $14 \mathrm{~d}$ interval, respectively; hydrogen peroxide + peroxyacetic acid (BioSafe Systems LLC, Hartford, CT) at 10 $\mathrm{mL} \cdot \mathrm{L}^{-1}(1 \%)$ and $20 \mathrm{~mL} \cdot \mathrm{L}^{-1}(2 \%)$ application rate in $7 \mathrm{~d}$ interval; sodium carbonate peroxyhydrate (BioSafe Systems LLC) at $3.59 \mathrm{~g} \cdot \mathrm{L}^{-1}(0.48 \mathrm{oz} / \mathrm{gal})$ and $7.18 \mathrm{~g} \cdot \mathrm{L}^{-1}(0.96 \mathrm{oz} / \mathrm{gal})$ application rate in $7 \mathrm{~d}$ interval; Reynoutria sachalinensis extract $(\mathrm{Marrone} \mathrm{Bio} \mathrm{Innovations}, \mathrm{Davis}, \mathrm{CA})$ at $10 \mathrm{~mL} \cdot \mathrm{L}^{-1}(1 \%)$ application rate in $7 \mathrm{~d}$ interval. $1 \mathrm{~g} \cdot \mathrm{L}^{-1}=0.1335 \mathrm{oz} / \mathrm{gal} ; 1 \mathrm{~mL} \cdot \mathrm{L}^{-1}=0.1280 \mathrm{fl} \mathrm{oz} / \mathrm{gal} ; 1 \mathrm{~mL} \cdot \mathrm{L}^{-1}=0.1 \%$

${ }^{\mathrm{y}}$ Experimental product (not labeled).

${ }^{\mathrm{x}} \mathrm{NC}=$ not classified.

treatments. All ninebark plants were naturally infected with powdery mildew. Symptomatic leaves were collected from both experiments to identify the causative organism. Microscopic observations under light microscope revealed masses of conidia and mycelium covering symptomatic tissues. To confirm pathogen identity, total DNA was extracted directly from plant tissue with the UltraClean Microbial DNA Isolation Kit (MO BIO Laboratories, Inc., Carlsbad, CA) following the manufacturer's instructions after each experiment. The ITS region of the ribosomal DNA was amplified by PCR using primer pair ITS1 and ITS4 (White et al., 1990). The sequences of the amplicon had $100 \%$ coverage and $100 \%$ identity to that of $P$. physocarpi.

The first experiment was conducted from 1 June 2016 to 29 June 2016. The plants were evaluated for powdery mildew disease severity and phytotoxicity on $8,15,22$, and 29 June 2016; and plant height and width were measured on 29 June 2016. The second experiment was conducted from 15 June 2016 to 20 July 2016. The plants were evaluated for powdery mildew disease severity and phytotoxicity on 22 and 29 June and on 6,13 , and 20 July 2016, and plant height and width were measured on 20 July 2016 . The average maximum temperatures for 1 to 30 June and 1 to 20 July were 30.3 and $35.4{ }^{\circ} \mathrm{C}$, respectively; and average minimum temperatures were 20.7 and $21.8^{\circ} \mathrm{C}$, respectively. Total rainfall was 1.21 and 2.12 inches, respectively.

The observations on powdery mildew disease severity and phytotoxicity were made in weekly intervals. Powdery mildew disease severity and phytotoxicity were evaluated based on the percentage of foliage exhibiting symptoms or phytotoxicity, using a scale of $0 \%$ to $100 \%$ foliage area affected. The disease progress (AUDPC) was calculated using the formula $\sum\left\{\left[\left(x_{\mathrm{i}}+x_{\mathrm{i}}-1\right) / 2\right]\left(t_{\mathrm{i}}-t_{\mathrm{i}}-1\right)\right\}$, where $x_{\mathrm{i}}$ is powdery mildew disease severity rating on each evaluation date and $\left(t_{\mathrm{i}}-t_{\mathrm{i}}-1\right)$ is the number of days between evaluations.

Disease severity, disease progress (AUDPC), plant height and width were compared among the treatments for both experiments. Oneway analysis of variance (ANOVA) was performed using general linear model (PROC GLM) to partition the variance between disease severity, disease progress (AUDPC), plant height and width into source attributable to treatments and errors using statistical software (SAS version 9.4 for windows; SAS Institute, Cary, NC). Treatment means were separated using Tukey's Studentized range test $(\alpha=0.05)$. All data met the ANOVA assumptions of normality and constant variance except for disease severity of Expt. 1, and disease progress (AUDPC) of Expts. 1 and 2, where variances were unequal. Welch's $t$ test was chosen to partition variance in disease severity; and disease progress into source attributable to treatment and errors assuming unequal variance (Welch, 1947; Zheng et al., 2012) and means were separated by least square means $(\alpha=0.05)$.

\section{Results}

Efficacy of sanitizers, biorational products, and fungicides in management of powdery mildew on ninebark-Expt. 1. The powdery mildew infection occurred naturally, and the disease pressure was low, with severity reaching $10 \%$ in the nontreated control (Table 2). All applied treatments, except the low rate of hydrogen peroxide + peroxyacetic acid (2.31 $\mathrm{mL} \cdot \mathrm{L}^{-1}$ total a.i. applied), significantly reduced the powdery mildew severity $(F=13.18, P=0.0008)$ and disease progress (AUDPC) $(F=18.39, P=0.0001)$ compared with the nontreated control. Azoxystrobin + benzovindiflupyr $\left(0.17\right.$ and $0.23 \mathrm{~g} \cdot \mathrm{L}^{-1}$ total a.i. applied at a 7- and 14-d interval), chlorothalonil + propiconazole $\left(1.12 \mathrm{~mL} \cdot \mathrm{L}^{-1}\right.$ total a.i. applied at a 14-d interval), azoxystrobin + tebuconazole $\left(0.16 \mathrm{~g} \cdot \mathrm{L}^{-1}\right.$ total a.i. applied at a 14-d interval), and the biorational product giant knotweed (Reynoutria sachalinensis) extract $\left(0.5 \mathrm{~mL} \cdot \mathrm{L}^{-1}\right.$ total a.i. applied at a $7-\mathrm{d}$ interval) effectively reduced the powdery mildew severity and were statistically different from the nontreated control. These five treatments, including chlorothalonil + propiconazole $\left(0.96 \mathrm{~mL} \cdot \mathrm{L}^{-1}\right.$ total a.i. applied at a 7-d interval), azoxystrobin + tebuconazole (0.11 g. $\mathrm{L}^{-1}$ total a.i. applied at a $14-\mathrm{d}$ interval), and sodium carbonate peroxyhydrate $\left(6.10 \mathrm{~g} \cdot \mathrm{L}^{-1}\right.$ total a.i. applied at a $7-\mathrm{d}$ interval) significantly lowered the progression of the powdery mildew disease progress (AUDPC) compared with the nontreated control. The higher rate of sodium carbonate peroxyhydrate and azoxystrobin + tebuconazole significantly reduced the disease severity compared with the lower rate when applied at the same interval; however, there were no significant differences between the higher and lower rates in reducing the disease progress (AUDPC).

A significant difference in final plant height was observed among the treatments $[F=3.83, P=0.001$ (Table 3)]. Plants treated with chlorothalonil + propiconazole (both rates), the high rate of hydrogen peroxide + peroxyacetic acid $\left(4.62 \mathrm{~mL} \cdot \mathrm{L}^{-1}\right.$ total a.i. applied), azoxystrobin + tebuconazole $(0.16$ $\mathrm{g} \cdot \mathrm{L}^{-1}$ total a.i. applied), and giant knotweed extract $\left(0.5 \mathrm{~mL} \cdot \mathrm{L}^{-1}\right.$ total a.i. applied) had significantly higher final height compared with the nontreated control. However, the final plant width did not significantly vary among treatments; it ranged from an average of 56 to $64 \mathrm{~cm}[F=0.95, P=0.51$ (Table 3)]. No phytotoxicity of applied treatments was observed during the entire experiment period.

Efficacy of sanitizers, biorational products, and fungicides in management of powdery mildew on ninebark-Expt. 2. Powdery mildew naturally occurred in ninebark plants, and moderate disease pressure was observed in Expt. 2. Significant difference among treatments for managing the powdery mildew disease severity $(F=156.75, P<0.0001)$ and AUDPC $(F=43.17, P<0.0001)$ were observed, with the nontreated control group exhibiting the higher disease severity (43\%) (Table 2). The fungicides azoxystrobin + benzovindiflupyr $\left(0.17\right.$ and $0.23 \mathrm{~g} \cdot \mathrm{L}^{-1}$ total a.i. applied at a 7- and 14-d interval, respectively), chlorothalonil + propiconazole $(0.96$ and $1.12 \mathrm{~mL} \cdot \mathrm{L}^{-1}$ total a.i. applied at a $7-$ and 14-d interval, respectively), sodium carbonate peroxyhydrate $\left(6.10 \mathrm{~g} \cdot \mathrm{L}^{-1}\right.$ total a.i. applied at a 7-d interval), azoxystrobin + tebuconazole $\left(0.11\right.$ and $0.16 \mathrm{~g} \cdot \mathrm{L}^{-1}$ total a.i. applied at a $14-$ $\mathrm{d}$ interval) and the biorational product giant 


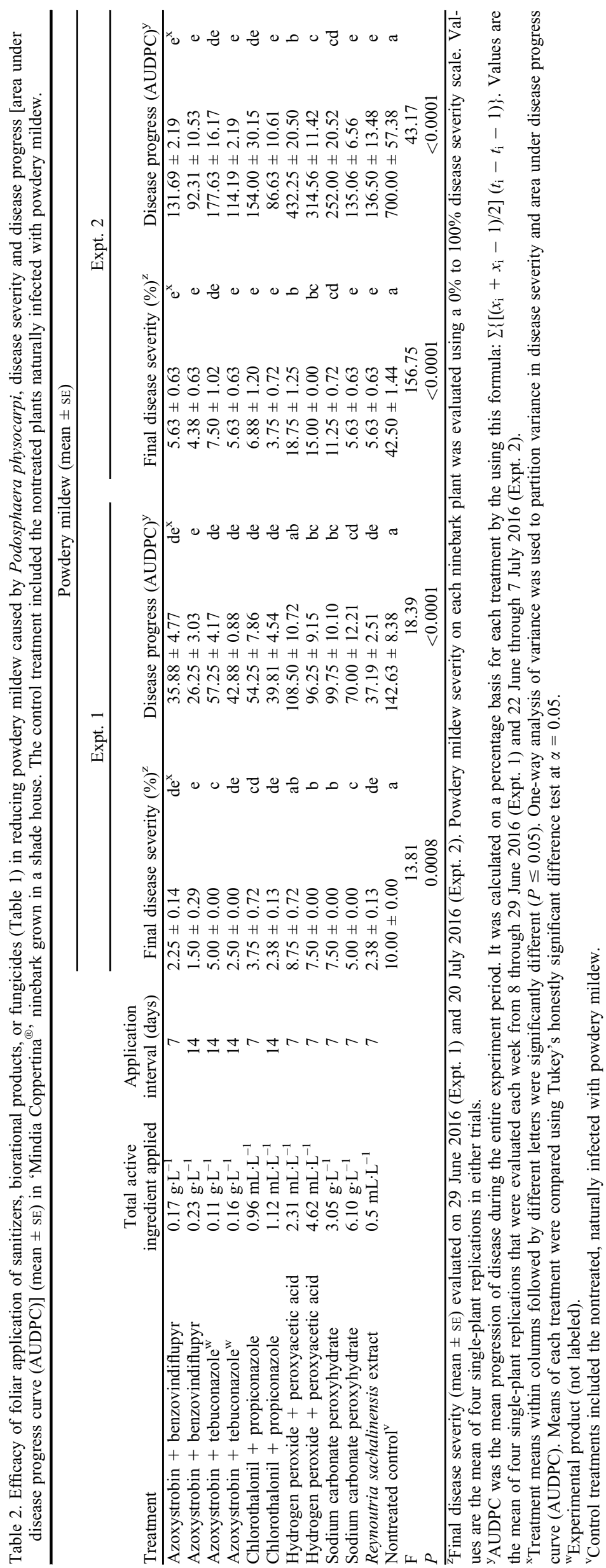

knotweed extract $\left(0.5 \mathrm{~mL} \cdot \mathrm{L}^{-1}\right.$ total a.i. applied at a 7-d interval) significantly reduced the powdery mildew disease severity compared with the nontreated control. These eight treatments also significantly lowered the powdery mildew disease progression (AUDPC) during entire experiment period (Table 2). The higher rate of sodium carbonate peroxyhydrate (6.10 g. $\mathrm{L}^{-1}$ total a.i. applied) significantly reduced the disease severity and AUDPC than its lower rate $\left(3.05 \mathrm{~g} \cdot \mathrm{L}^{-1}\right.$ total a.i. applied) when both were applied at a 7-d interval. Similarly, the higher rate of hydrogen peroxide + peroxyacetic acid $\left(4.62 \mathrm{~mL} \cdot \mathrm{L}^{-1}\right.$ total a.i. applied) also significantly lowered the disease progress (AUDPC) more than its lower rate (2.31 $\mathrm{mL} \cdot \mathrm{L}^{-1}$ total a.i. applied) when both rates were applied at a 7-d interval; however, they were statistically similar in reducing the final disease severity.

The final plant width and height did not vary among the treatments (width: $F=1.37$, $P=0.23$; height: $F=0.66, P=0.76$ ), which ranged from an average of 55.0 to $70.0 \mathrm{~cm}$ and 68.0 to $90.0 \mathrm{~cm}$, respectively (Table 3 ). Phytotoxicity symptoms tip browning, curling of new growth, and leaf distortion of sanitizer hydrogen peroxide + peroxyacetic acid (2.31 and $4.62 \mathrm{~mL} \cdot \mathrm{L}^{-1}$ total a.i. applied), and azoxystrobin + benzovindiflupyr $(0.17$ and $0.23 \mathrm{~g} \cdot \mathrm{L}^{-1}$ total a.i. applied) were observed in Expt. 2 . The phytotoxicity severity was $2.5 \%$ and $8.8 \%$ on the ninebark plant treated with 2.31 and $4.62 \mathrm{~mL} \cdot \mathrm{L}^{-1}$ total a.i. applied of hydrogen peroxide + peroxyacetic acid, respectively, whereas it was $2.5 \%$ and $6.3 \%$ on the ninebark plant treated with 0.17 and 0.23 $\mathrm{g} \cdot \mathrm{L}^{-1}$ total a.i. applied of azoxystrobin + benzovindiflupyr, respectively (data not shown).

\section{Discussion}

In this current study, the efficacy of sanitizers, biorational products, and fungicides were screened against powdery mildew disease management on ninebark. The nontreated, naturally infected plants with powdery mildew consistently showed the higher disease severity and disease progress (AUDPC) in both experiments. However, powdery mildew disease severity was higher in Expt. 2 than in Expt. 1, probably due to favorable microclimate (warm humid) for proliferation of powdery mildew in the commercial nursery.

The giant knotweed extract (Regalia; Marrone Bio Innovations, Davis, CA), an elicitor for plant defense, effectively reduced the powdery mildew disease severity and disease progress in this current study. Similar results of giant knotweed extract in reducing powdery mildew in cucumber (Cucumis sati$v u s$ ), tomato (Solanum lycopersicum), and apple (Malus domestica) (Baysal-Gurel and Miller, 2015; DeLong et al., 2018; Giotis et al., 2012; Herger and Klingauf, 1990; Rur et al., 2018; Zhang et al., 2016). The antifungal activity of giant knotweed extract is by activating the plant defense system, preventing the growth and germination of fungal conidia (Bélanger and Benyagoub, 1997; Konstantinidou-Doltsinis et al., 2006). 


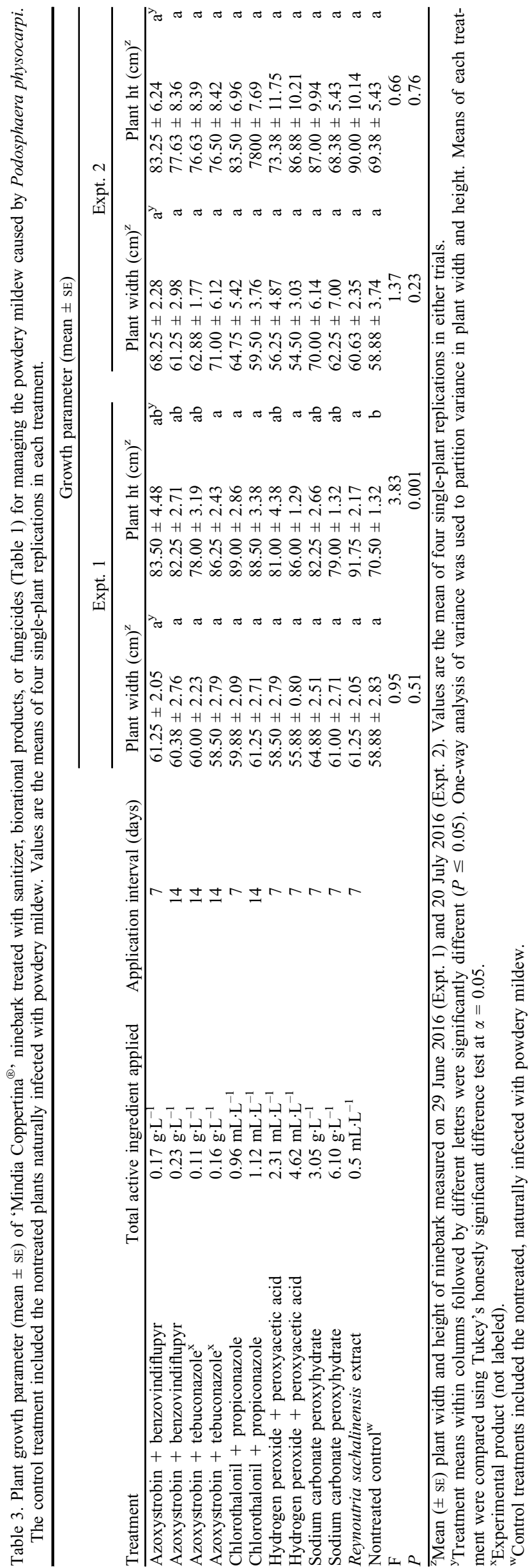

Margaritopoulou et al. (2020) suggested that plant defense by giant knotweed application is due to the activation of the salicylic acid (SA) defense pathway, which was demonstrated by formation of callose, accumulation of hydrogen peroxide, and SA, along with increased $p$-coumaric and caffeic acid. In our current study, the efficacy of giant knotweed extract was equivalent to chemical fungicides in reducing the powdery mildew disease severity on ninebark. This might be because of the moderate disease pressure (less than $50 \%$ ) during the study. But a varying efficacy of giant knotweed extract had been observed by Konstantinidou-Doltsinis et al. (2006) in reducing the powdery mildew of tomato in a greenhouse production system. However, it has a good potential to be used in combination or rotation with fungicides when disease pressure is high.

The higher rate of hydrogen peroxide + peroxyacetic acid $\left[4.62 \mathrm{~mL} \cdot \mathrm{L}^{-1}\right.$ total a.i. applied (ZeroTol 2.0; BioSafe Systems, Hartford, CT)] was slightly effective in reducing powdery mildew disease, whereas the lower rate $\left(2.31 \mathrm{~mL} \cdot \mathrm{L}^{-1}\right.$ total a.i. applied) was not effective in reducing the disease severity and disease progress (AUDPC) on ninebark. These results were like results observed by Tjosvold and Koike (2001), who relate that spraying of hydrogen peroxide + peroxyacetic acid showed moderate powdery mildew disease control in miniature rose (Rosa $\times$ 'Fiesta Parade'). However, the higher concentration of hydrogen peroxide + peroxyacetic acid $\left(5.78 \mathrm{~mL} \cdot \mathrm{L}^{-1}\right.$ total a.i. applied) significantly reduced the powdery mildew disease severity in pumpkin [Cucurbita pepo $(\mathrm{Gu}-$ bler et al., 2014)]. The hydrogen peroxide + peroxyacetic acid is a nonsystemic chemical whose efficacy is based on contact (Tjosvold and Koike, 2001). The contact fungicides, sometimes, can easily be washed off by rain or be degraded by the environmental conditions (temperature, moisture) that might limit their efficacy, allowing the pathogen to escape the treatment's effect. Another possibility, the phytotoxic effect of hydrogen peroxide + peroxyacetic acid on ninebark, could have made the plant more vulnerable to powdery mildew disease. Tjosvold and Koike (2001) also observed the necrosis of leaf or leaf margin and chlorosis of young shoots in miniature rose due to application of hydrogen peroxide + peroxyacetic acid.

The two rates of sodium carbonate peroxyhydrate (GCPRO; BioSafe Systems, Hartford, CT) effectively controlled the powdery mildew disease severity and disease progress compared with the nontreated control; however, the higher rate of sodium carbonate peroxyhydrate $\left(6.10 \mathrm{~g} \cdot \mathrm{L}^{-1}\right.$ total a.i. applied) was significantly more effective than the lower rate $\left(3.05 \mathrm{~g} \cdot \mathrm{L}^{-1}\right.$ total a.i. applied). Similar results were observed by Abramians and Gubler (2017) and Nguyen et al. (2016), who related that application of sodium carbonate peroxyhydrate significantly reduced the powdery mildew disease severity on pumpkin and grapevine (Vitis vinifera). The antifungal mechanism of sodium carbonate 
peroxyhydrate could be due to its ability to transform into hydrogen peroxide and sodium carbonate in presence of moisture, causing oxidative damage to mitochondrial cells or other vital component resulting death of target organism (National Center for Biotechnology Information, 2020; Palmer et al., 1997).

The fungicide azoxystrobin + benzovindiflupyr (Mural; Syngenta, Greensboro, NC) significantly reduced the powdery mildew disease severity and disease progress (AUDPC) compared with the nontreated control. The similar efficacy of azoxystrobin + benzovindiflupyr in reducing the powdery mildew of flowering dogwood and soybean (Glycine max) were observed (Assunção et al., 2019; Baysal-Gurel and Simmons, 2018). In this current study the efficacy of both rates of azoxystrobin + benzovindiflupyr were statistically like each other in reducing the powdery mildew severity and disease progress (AUDPC). The treatment is mixture of two class fungicides, i.e., SDHI and quinone outside inhibitor (QoI) (Fungicide Resistance Action Committee, 2020). Both class of fungicides interfere with the cellular respiration of the target organism by inhibiting the electron transport system in mitochondria. This results in low or no energy generation in the target organism, ultimately causing death (Veloukas and Karaoglanidis, 2012; Zeng et al., 2015). The mixture of two classes of fungicides may have provided multiple target sites for better management of powdery mildew on ninebark. However, a low phytotoxicity was observed in plants treated with azoxystrobin + benzovindiflupyr in Expt. 2. The phytotoxicity severity was less in plants treated with a lower rate than with a higher rate of azoxystrobin + benzovindiflupyr. Similarly, two rates of azoxystrobin + tebuconazole (experimental product; OHP, Bluffton, SC) effectively lowered the disease severity and disease progress (AUDPC). The efficacy of both rates was statistically like each other in controlling powdery mildew disease.

The application of chlorothalonil + propiconazole (Concert II; Syngenta, Greensboro, NC) showed effective results in controlling powdery mildew disease severity and disease progress (AUDPC) compared with the nontreated control. Similar results were observed by McGrath and Shishkoff (2001) and Mmbaga and Sheng (2002), who report that chlorothalonil and propiconazole (alone or in combination with fungicides) reduced the powdery mildew of cucurbits and flowering dogwood (Cornus florida). Chlorothalonil is a contact and multisite fungicide, whereas the propiconazole is systemic fungicide; therefore, the greater efficacy in reducing the powdery mildew severity in this current study might have been due to added flexibility (multiple target site) provided by these two a.i. against the phytopathogen. Because the mixture of chlorothalonil + propiconazole is a broad-spectrum fungicide, it is a good candidate to use in combination or in rotation with different biorational products or single-site fungicides. The application of chlorothalonil + propiconazole at a 14-d alternate rotation with strobilurin or a succinate dehydrogenase inhibitor (SDHI) class of fungicides significantly reduced the powdery disease severity in flowering dogwood (Baysal-Gurel and Simmons, 2018).

The final plant height and width were not statistically different from nontreated control plants. Even though the treated plants showed reduced powdery mildew severity, the photosynthetic potential of plants was not substantially influenced for significant increase in plant growth parameters. Phytotoxicity of treatments were not observed in Expt. 1; however, there was mild phytotoxicity of azoxystrobin + benzovindiflupyr and hydrogen peroxide + peroxyacetic acid in Expt. 2, which might have been due to the change in environmental conditions such as higher temperature than Expt. 1.

The current research was designed with the purpose of helping nursery producers for the better management of powdery mildew on ninebark. The treatments such as azoxystrobin + benzovindiflupyr at 0.17 and 0.23 $\mathrm{g} \cdot \mathrm{L}^{-1}$ total a.i. applied, chlorothalonil + propiconazole at $1.12 \mathrm{~mL} \cdot \mathrm{L}^{-1}$ total a.i. applied, Azoxystrobin + tebuconazole at 0.11 and $0.16 \mathrm{~g} \cdot \mathrm{L}^{-1}$ total a.i. applied, and giant knotweed extract $\left(0.5 \mathrm{~mL} \cdot \mathrm{L}^{-1}\right.$ total a.i. applied) significantly controlled the powdery mildew disease severity and disease progression in both experiments. Even though the application of azoxystrobin + benzovindiflupyr had shown the greater efficacy in reducing disease severity and disease progress, it is not advised for multiple applications of this treatment, and it is suggested to use lower rates due to the risk of developing pathogen resistance. Lebeda et al. (2010) reported that cucurbit powdery mildew (Podosphaera xanthii) had developed resistance to seven different single site fungicides (benzimidazole, DMI, morpholine, hydroxypyrimidine, phosphorothiolate, QoI, and pyridine carboxamides). The fungicides and biorational products should be applied by combining or rotating for effective suppression of disease and to avoid the chance of the development of pathogen resistance. For example, the biorational products giant knotweed extract and fungicides chlorothalonil + propiconazole can be used in combination or alternate rotation when powdery mildew disease pressure is low to medium; however, the fungicide azoxystrobin + benzovindiflupyr should be reserved for severe or higher powdery mildew disease severity cases. A good strategy for better management of powdery mildew would be adopting integrated management tools: hygiene nursery practices, using resistant cultivars, proper cultural practices, and rotation of biorational products and chemicals. In the paucity of knowledge for managing ninebark powdery mildew, the findings of this current study can assist woody ornamental producers for better and sustainable management of powdery mildew disease on ninebark.

\section{Literature Cited}

Abramians, A.A. and W.D. Gubler. 2017. Control of grape powdery mildew with synthetic, biological and organic fungicides: 2017 field trials. University of California Cooperative Extension, Department of Plant Pathology, Davis, CA. $<$ https://ucanr.edu/sites/eskalenlab/files/311062. pdf $>$.

Assunção, H.H.d., S.M. Silva, G.S. Alves, C.H. Zandonadi, and J.P. da Cunha. 2019. Electrostatic spraying effect on spray deposition and powdery mildew control in soybean. Eng. Agr. 39:721-728.

Baysal-Gurel, F. and S. Miller. 2015. Management of powdery mildew in greenhouse tomato production with biorational products and fungicides. Acta Hort. 1069:179-183.

Baysal-Gurel, F. and T. Simmons. 2018. Evaluation of fungicide rotations at different application intervals for the control of powdery mildew of dogwood, 2017. Plant Disease Management Report OT005. Online publication. The American Phytopathological Society, St. Paul, MN.

Baysal-Gurel, F., T. Simmons, F.A. Avin, R. Bika, and C. Jennings. 2020. First report of powdery mildew on Physocarpus opulifolius caused by Podosphaera physocarpi in Tennessee. Plant Dis., doi: 10.1094/PDIS-06-20-1286-PDN.

Bélanger, R. and M. Benyagoub. 1997. Challenges and prospects for integrated control of powdery mildews in the greenhouse. Can. J. Plant Pathol. 19:310-314.

DeLong, C.N., K.S. Yoder, A.E. Cochran, S.W. Kilmer, W.S. Royston, Jr., L.D. Combs, and G.M. Peck. 2018. Apple disease control and bloom-thinning effects by lime sulfur, regalia, and jms stylet-Oil. Plant Health Prog. 19: 143-152.

Dirr, M.A. 1998. Manual of woody landscape plants: Their identification, ornamental characteristics, culture, propagation and uses. Stipes Publishing LLC, Champaign, IL.

Dirr, M.A. 2011. Dirr's hardy trees and shrubs: An illustrated encyclopedia. Timber Press, Portland, OR.

Fungicide Resistance Action Committee. 2020. FRAC code list 2020: Fungicides sorted by mode of action (including FRAC code numbering). 23 Apr. 2020.<https://www.frac.info/ docs/default-source/publications/frac-code-list/ frac-code-list-2020final5d632b2c512362eb9a1e ff00004acf5d.pdf?sfvrsn=f940499a $\_$> .

Giotis, C., E. Markellou, A. Theodoropoulou, G. Kostoulas, S. Wilcockson, and C. Leifert. 2012. The effects of different biological control agents (BCAs) and plant defence elicitors on cucumber powdery mildew (Podosphaera xanthii). Org. Agr. 2:89-101.

Gubler, W.D., T.T. Nguyen, and N.S. Morris. 2014. Powdery mildew control of cucurbit with organic and synthetic fungicides: 2014 field trial. University of California Cooperative Extension, Department of Plant Pathology, Davis, CA. <http://plantpathology.ucdavis.edu/intranet/ 199597.pdf>.

Herger, G. and F. Klingauf. 1990. Control of powdery mildew fungi with extracts of the giant knotweed, Reynoutria sachalinensis (Polygonaceae). Meded. Fac. Landbouwwet. Rijksuniv. Gent 55:1007-1014.

Konstantinidou-Doltsinis, S., E. Markellou, A.-M. Kasselaki, M. Fanouraki, C. Koumaki, A. Schmitt, A. Liopa-Tsakalidis, and N. Malathrakis. 2006. Efficacy of Milsana ${ }^{\circledR}$, a formulated plant extract from Reynoutria sachalinensis, against powdery mildew of tomato (Leveillula taurica). BioControl 51:375-392.

Lebeda, A., M.T. McGrath, and B. Sedláková. 2010. Fungicide resistance in cucurbit powdery 
mildew fungi, p. 221-246. In: O. Carisse (ed.). Fungicides. InTech, Rijeka, Croatia.

Lubell, J., M. Brand, and J. Lehrer. 2011. Susceptibility of eastern ninebark (Physocarpus opulifolius (L.) Maxim.) cultivars to powdery mildew. J. Environ. Hort. 29:105-107.

Margaritopoulou, T., E. Toufexi, D. Kizis, G. Balayiannis, C. Anagnostopoulos, A. Theocharis, L. Rempelos, Y. Troyanos, C. Leifert, and E. Markellou. 2020. Reynoutria sachalinensis extract elicits SA-dependent defense responses in courgette genotypes against powdery mildew caused by Podosphaera xanthii. Sci. Rep. 10:1-17.

McGrath, M.T. and N. Shishkoff. 2001. Resistance to triadimefon and benomyl: Dynamics and impact on managing cucurbit powdery mildew. Plant Dis. 85:147-154.

Mmbaga, M.T. and H. Sheng. 2002. Evaluation of biorational products for powdery mildew management in Cornus florida. J. Environ. Hort. 20:113-117.

National Center for Biotechnology Information. 2020. Pubchem compund summary for CID 159762, sodium percarbonate. 7 June 2020. $<$ https://pubchem.ncbi.nlm.nih.gov/compound/ Sodium-percarbonate $>$.

Nguyen, T.T., N.S. Morris, and W.D. Gubler. 2016. Fungicide control of powdery mildew of cucurbit: 2016 field trial. University of
California Cooperative Extension, Department of Plant Pathology, Davis, CA. <https://ucanr. edu/sites/eskalenlab/files/311057.pdf $>$.

Palmer, C.L., R.K. Horst, and R.W. Langhans 1997. Use of bicarbonates to inhibit in vitro colony growth of Botrytis cinerea. Plant Dis. $81: 1432-1438$

Pscheidt, J.W. and C.M. Ocamb. 2000. Pacific northwest plant disease management handbook. Oregon State University Extension publication, Corvallis, OR.

Rur, M., B. Rämert, M. Hökeberg, R.R. Vetukuri, L. Grenville-Briggs, and E. Liljeroth. 2018 Screening of alternative products for integrated pest management of cucurbit powdery mildew in Sweden. Eur. J. Plant Pathol. 150:127-138.

Tjosvold, S. and S.T. Koike. 2001. Evaluation of reduced risk and other biorational fungicides on the control of powdery mildew on greenhouse roses. Acta Hort. 547:59-67.

Veloukas, T. and G.S. Karaoglanidis. 2012. Biological activity of the succinate dehydrogenase inhibitor fluopyram against Botrytis cinerea and fungal baseline sensitivity. Pest Mgt. Sci. 68:858-864.

Welch, B. 1947. The generalization of student's problem when several different population variances are involved. Biometrika 34:23-35.

Wheeler, A. and E. Hoebeke. 1985. The insect fauna of ninebark, Physocarpus opulifolius
(Rosaceae). Proc. Entomol. Soc. Wash. 87: 356-370.

White, T.J., T.D. Bruns, S. Lee, and J. Taylor. 1990. Amplification and direct sequencing of fungal ribosomal RNA genes for phylogenetics, p. 315-322. In: M. Innis, D. Gelfand, J. Shinsky, and T.J. White (eds.). PCR protocols: a guide to methods and applications. Academic Press, San Diego, CA.

Zeng, F., E. Arnao, G. Zhang, G. Olaya, J. Wullschleger, H. Sierotzki, R. Ming, B. Bluhm, J. Bond, and A. Fakhoury. 2015. Characterization of quinone outside inhibitor fungicide resistance in Cercospora sojina and development of diagnostic tools for its identification. Plant Dis. 99:544-550.

Zhang, S., Z. Mersha, G.E. Vallad, and C.-H. Huang. 2016. Management of powdery mildew in squash by plant and alga extract biopesticides. Plant Pathol. J. 32:528-536.

Zheng, L., J.M. Diamond, and D.L. Denton. 2012. Evaluation of whole effluent toxicity data characteristics and use of welch's t-test in the test of significant toxicity analysis. Environ. Toxicol. Chem 32:468-474.

Zlesak, D.C. 2012. Physocarpus opulifolius (L.) Maxim 'Donna May': A new compact, purpleleafed landscape shrub. HortScience 47:13721374. 